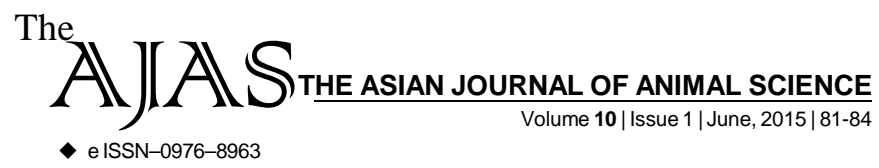

DOI : 10.15740/HAS/TAJAS/10.1/81-84 Visit us | www.researchjournal.co.in $\mathbf{S}$

\title{
Measurement of readability of developed and standardized e- booklet on dairy farming
}

\section{RUPENDER KAUR AND UPENDRA KUMAR}

Author for Corresponding -

\section{UPENDRA KUMAR}

Krishi Vigyan Kendra, (S.K.R.A.U.), BEECHWAL (RAJASTHAN) INDIA

Email: ukmeel@gmail.com

See end of the article for

Coopted authors'
ABSTRACT...... Responsibility and intervention of media in rural transformation is becoming more imperative and challenging. Undoubtedly contribution of media in dairy farming is noteworthy but relatively little efforts have been made to disseminate the scientific knowhow amongst the lives. The study was conducted with 30 literate women in Hanumangarh and Sriganganagar Districts of Rajasthan. The findings of the study shows that the fog index value for e-booklet was 6.612, which shows high readability, majority of the respondents $(76.67 \%)$ read the e-booklet fluently, mean weighted score for e-booklet was 2.45 , total 5 words in e-booklet were considered as difficult to read, majority of the respondents (80\%) reported that the e-booklet was easy to read, mean score obtained by the respondents for readability of e-booklet was 7.6 out of 8 score range, majority of the respondents $(70 \%)$ obtained readability score 'Above mean score'.

KEY WORDS...... Readability level, E-booklet, Dairy farming

HOW TO CITE THIS ARTICLE - Kaur, Rupender and Kumar, Upendra (2015). Measurement of readability of developed and standardized e-booklet on dairy farming. Asian J. Animal Sci., 10(1) : 8184.

ARTICLE CHRONICLE - Received : 15.04.2015; Accepted : 28.05.2015 